\title{
ASSESSMENT OF HYDROCARBONS SUBSOIL AND GROUNDWATER POLLUTION IN A REFINERY OCCUPIED PROPERTY AT THE OLD INDUSTRIAL ZONE OF ATHENS - PIREAUS, GREECE
}

\author{
Zotiadis V. ${ }^{1}$, and Kollios A. ${ }^{1}$ \\ ${ }^{1}$ Edafomichaniki S.A., Em. Papadaki 19, N. Iraklio 141 21, Athens, vzotiad@edafomichaniki.gr, \\ akollios@edafomichaniki.gr
}

\begin{abstract}
Industrial activities that took place in the old industrial zone of Athens-Piraeus widespread pollution in natural systems. This specific environmental site assessment presents subsoil and groundwater pollution data by petroleum hydrocarbons in a property occupied by a small scale refinery the last 50 years. Additionally the vertical distribution and horizontal variability of pollution is analysed as a result of several point sources existence such as underground storage tanks. Environmental survey site works conducted by boreholes performance and installation of stand-pipe type piezometers for groundwater monitoring. Totally 32 soil core samples were analyzed for total petroleum hydrocarbons and additionally 4 soil core sub-samples where volatile organic compounds maximum values were recorded, analyzed for aromatic hydrocarbons. Petroleum hydrocarbons values in subsoil and groundwater range from 310 to $8130 \mathrm{mg} \mathrm{Kg}^{-1}$ and 0.6 to $2550 \mathrm{mg} / \mathrm{l}$ respectively. This paper provides hydrocarbons pollution data of the site and demonstrates the need for an environmental site assessment study before any investment and development action takes place in brownfield's areas.
\end{abstract}

Key words: TPH, PAHs, mineral oils, contamination.

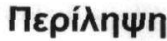

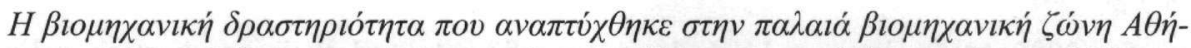

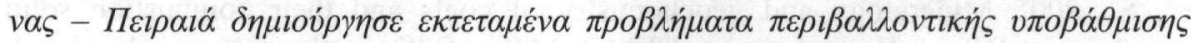

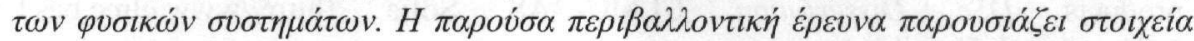

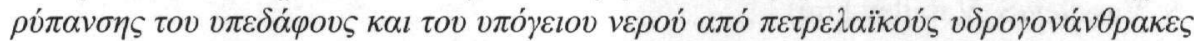

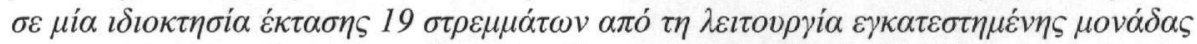

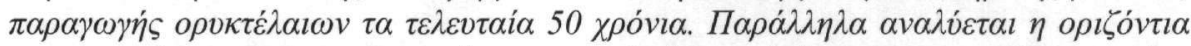

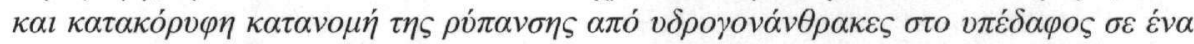

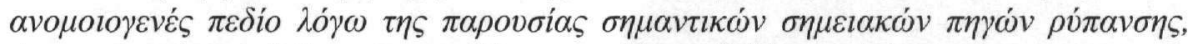

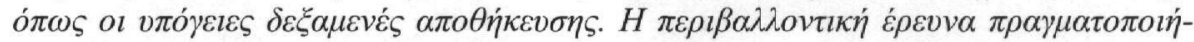

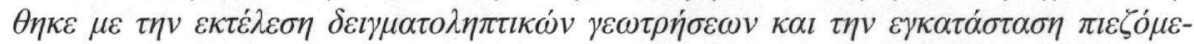

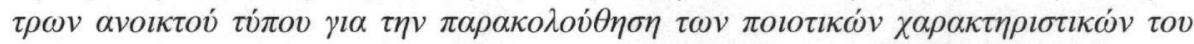

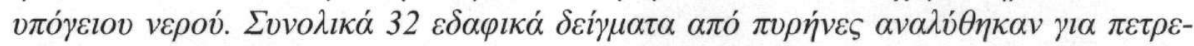

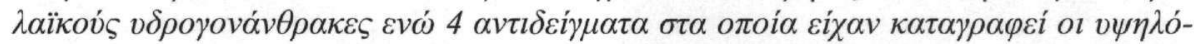

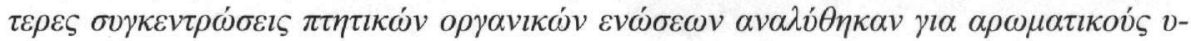




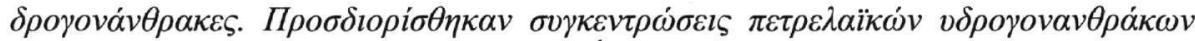

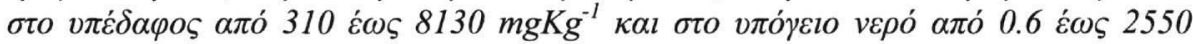

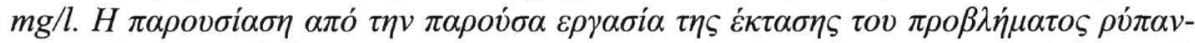

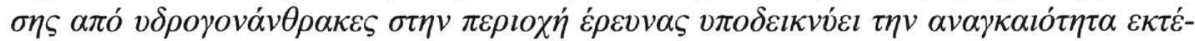

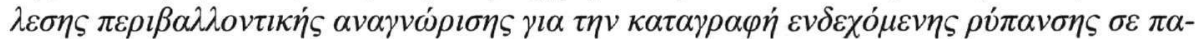

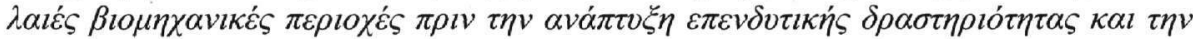
$\alpha \lambda \lambda \alpha \gamma \dot{\eta} \tau \eta \varsigma \chi \rho \dot{\eta} \sigma \eta \varsigma \gamma \eta \varsigma$.

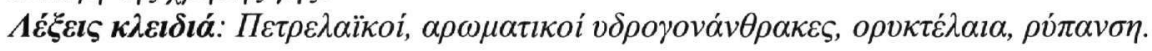

\section{Introduction}

Remediation and development of contaminated land demands thorough understanding of the nature and extent of soil contamination, i.e. determination of key- contaminants and their mobility/toxicity, as well as delineation of vertical and horizontal spatial distribution of contamination. Thus, environmental surveys prior to development actions should be a common practice in brownfield's areas. This paper presents the findings of such an investigation at an urban site within the old industrial zone of Athens - Piraeus, Greece.

This particular Environmental Site Assessment Phase II study was performed in parallel with a geotechnical study within an area of $19000 \mathrm{~m}^{2}$ which was occupied by a small scale refinery over the past 50 years. An Environmental Site Assessment Phase I study was previously conducted to identify Recognized Environmental Conditions, as defined by the American Society for Testing and Materials Standard E 1527 - 05 and presented the Environmental Risks at the site from the past refinery operation. According to the topographical layout of the refinery the main sections during production included several Underground Storage Tanks (USTs) of raw materials (petroleum, solvents, furfuraldehyde) and products (minerals oils, paraffin's and asphalt), distillation unit, chimneys, chemical and office buildings, washing and paint operations unit, warehouses, internal sewage system and other secondary buildings (machinery, workers changing rooms, etc).

Nowadays a new land use was planned for the site with the development of a commercial centre building with two basements. The objectives of the geochemical study were to assess the level of soil and groundwater organic pollution by hydrocarbons, as well as vertical distribution and horizontal variability of pollution at different depth horizons within the site before development.

\section{Geology - Stratigraphy}

The geology of the area comprises Quaternary and Neogene sediments in increasing geological age (IGME 1986):

- Holocene formations: alluvial deposits (sands, clays, gravels) in intercalations with loose conglomerate.

- Pleistocene formations: Fluvial deposits, conglomerate in intercalations with thin horizons of breccias, mudstones, sandstones and sandy marls.

The stratigraphy of the area was investigated by performance of four boreholes with codes G1 to G4 till the depth of $30 \mathrm{~m}$ and the simplified geotechnical model comprises the following layers:

- LAYER I: Man made deposits

- LAYER II: Silt, silty clay with sand to lean clay (ML) (ML-CL) (CL).

- LAYER III: Silt, silty sand to sandy silt (ML) (SM-ML).

- LAYER IV: Clay (CL).

- LAYER V: Silty-clayey gravel, clayey sand to silty sand (GM-GC) (SC) (SM). 
Hydrogeological monitoring during a two years period revealed that groundwater level is found between depth $5.80 \mathrm{~m}$ to $6.10 \mathrm{~m}$ with a low hydraulic gradient of about $2 \%$ (similar to the site morphology) with a NNW - SSE direction.

\section{Materials and methods}

A total of 32 soil core samples were collected from the studied site. Eight boreholes with codes $\mathrm{C} 1$ to $\mathrm{C} 8$ reaching a maximum investigation depth of $10.50 \mathrm{~m}$ were drilled inside the field following the specifications of USEPA 1996b at locations as shown in Figure 1. During site works Volatile Organic Compounds (VOCs) were measured in core samples at every single meter of penetration using a Photo Ionization Detector. Stand-type piezometers were installed at performed boreholes for groundwater level and quality monitoring. From each borehole, soil core samples were collected from four horizons (A, B, C, D) at depths of $A=3 \mathrm{~m}, \mathrm{~B}=5 \mathrm{~m}, \mathrm{C}=7 \mathrm{~m}$ and $\mathrm{D}=9 \mathrm{~m}$ by mixing the material from $10 \mathrm{~cm}$ above and below the specific depth to produce the bulk sample. Sampling depths were selected on a basis of soil material differentiation according to geotechnical data and the design of the environmental site investigation (EPA/240/R-02/005).

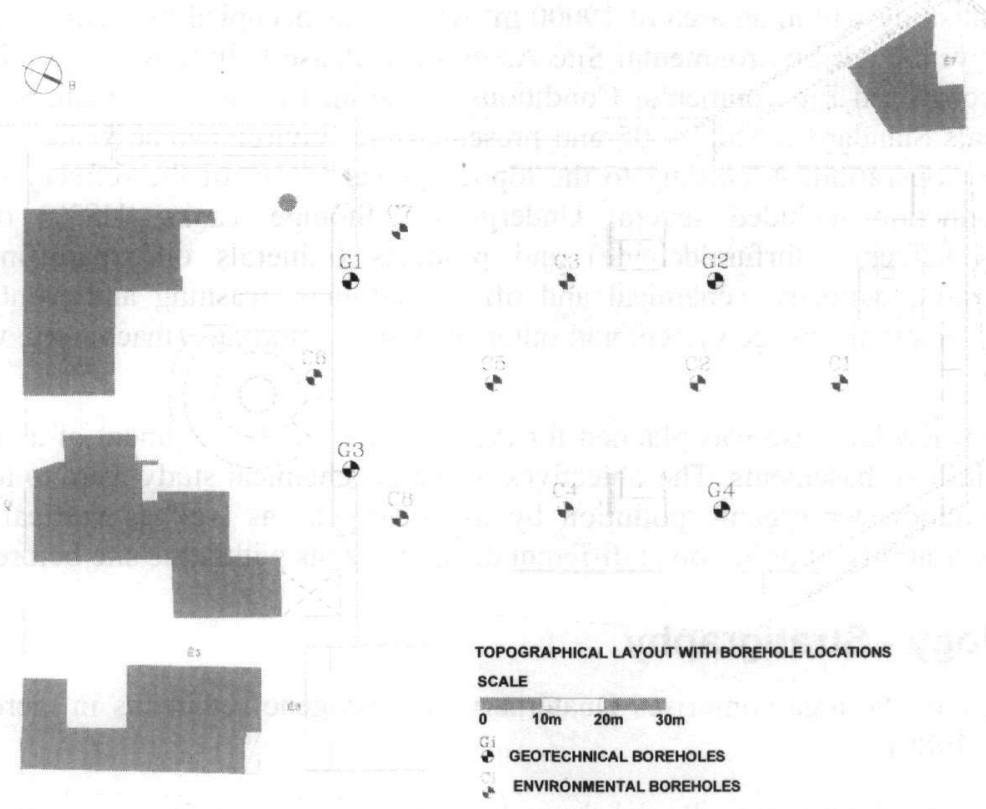

Figure 1 - Map of the sampling area showing locations of the performed geotechnical and environmental boreholes

The core samples were collected using stainless steel equipment, stored in jars of $500 \mathrm{ml}$ volume and preserved on site in portable refrigerator up to their transportation to the laboratory. All chemical analysis were performed at an accredited by ESYD laboratory in Athens, Greece. Thirty two soil core samples were analyzed for Total Petroleum Hydrocarbons (TPH) using Gas Chromatography according to EPA 8015b method (USEPA 1986a). Additionally, four core subsamples were selected on a basis of higher recorded VOCs values and analyzed for Polycyclic Aromatic Hydrocarbons (PAHs) using Gas Chromatography according to EPA 8100 method (USEPA 1986a). Analytical precision was assessed by using analytical duplicate samples and was reported to be better than $\pm 3 \%$. 
Water samples were also collected according to ASTM D 4448-85a specification using standard Teflon bailers, 11t capacity from the groundwater monitors. The samples were analyzed for Total Petroleum Hydrocarbons using Gas Chromatography according to EPA 8015b method and SW846 specifications (USEPA 1986a).

\section{Results and discussion}

\subsection{Volatile Organic Compounds (VOCs)}

The Volatile Organic Compounds values in core samples $(n=80)$ range from 0 to $23 \mathrm{ppm}$. Low VOCs values is a result of potential biodegradation, volatilization or migration of volatile organic compounds and express the nature of contamination from heavy hydrocarbon fractions at the area.

\subsection{Polycyclic Aromatics Hydrocarbons (PAHs)}

The analytical results of PAHs values in four selected core samples where VOCs maximum values were recorded, are presented in Table 1.

Table 1 - Analytical results of PAHs concentrations in selected cores samples

\begin{tabular}{|l|c|c|c|c|}
\hline \multicolumn{1}{|c|}{ Chemical compound } & $\begin{array}{c}\text { Borehole C3 } \\
\text { Horizon C } \\
\text { mgKg }^{-1}\end{array}$ & $\begin{array}{c}\text { Borehole C5 } \\
\text { Horizon D } \\
\text { mgKg }^{-1}\end{array}$ & $\begin{array}{c}\text { Borehole C1 } \\
\text { Horizon D } \\
\text { mgKg }^{-1}\end{array}$ & $\begin{array}{c}\text { Borehole C7 } \\
\text { Horizon A } \\
\text { mgKg }^{-1}\end{array}$ \\
\hline TPH & 3860 & 1710 & 2660 & 800 \\
\hline PAH (sum 11) & $<1,604$ & $<0,258$ & $<0,494$ & $<0,120$ \\
\hline Anthracene & 0,012 & 0,010 & $<0,005$ & $<0,005$ \\
\hline Fluoranthene & 0,009 & 0,009 & 0,008 & $<0,005$ \\
\hline Pyrene & 0,163 & 0,030 & 0,053 & $<0,020$ \\
\hline Benzo(1,2)anthracene & 0,850 & 0,070 & 0,200 & $<0,010$ \\
\hline Chrysene & 0,450 & 0,054 & 0,144 & $<0,010$ \\
\hline Benzo(3,4)fluranthene & 0,060 & $<0,010$ & 0,024 & $<0,010$ \\
\hline Benzo(11,12)fluranthene & $<0,005$ & $<0,005$ & $<0,005$ & $<0,005$ \\
\hline Benzo(3,4)pyrene & $<0,005$ & $<0,010$ & $<0,005$ & $<0,005$ \\
\hline Dibenzo-1,2:5,6anthracene & $<0,010$ & $<0,010$ & $<0,010$ & $<0,010$ \\
\hline Benzo(1,12)perylene & $<0,020$ & $<0,020$ & $<0,020$ & $<0,020$ \\
\hline Ideno(1,2,3-cd)pyrene & $<0,020$ & $<0,020$ & $<0,020$ & $<0,020$ \\
\hline
\end{tabular}

There are no official regulatory levels for petroleum and aromatic hydrocarbons in soils issued by the Greek government to help interpret the results. The detected values of the eleven aromatic hydrocarbon compounds are lower than the target values for non-contaminated soils as established by the Dutch List (2000) relative code which is widely used in Europe in Environmental Site Assessment studies. Generally the determined low PAHs values agree with the recorded low VOCs values as a result of the nature of contamination.

\subsection{Total Petroleum Hydrocarbons (TPH)}

When petroleum products are released into the environment, changes in product composition take place. Collectively, these changes are referred to as weathering including as main processes dissolution in water, volatilization and biodegradation (Mackay et al. 1992). The approach which has often been taken in the risk assessment of weathered petroleum mixtures has been based on "Total Petroleum Hydrocarbons" (TPH) measurements. The Total Petroleum Hydrocarbons (C6-C28) and TPH-Gasoline Range Organics (C6 - C10) as well as TPH-Diesel Range Organics (C11 - 
C28) values of the core samples are presented in Table 2, including the mean, median, standard deviation, range, minimum and maximum.

Table 2 - Statistical data of TPH, TPH-GRO and TPH-DRO values in core samples $(n=32)$

\begin{tabular}{|c|c|c|c|c|c|c|}
\hline \multirow{2}{*}{ Parameter } & Mean & Median & $\mathbf{S D}^{\mathbf{a}}$ & Range & Min & Max \\
\hline & $\mathrm{mgKg}^{-1}$ & $\mathrm{mgKg}^{-1}$ & $\mathrm{mgKg}^{-1}$ & $\mathrm{mgKg}^{-1}$ & $\mathrm{mgKg}^{-1}$ & $\mathrm{mgKg}^{-1}$ \\
\hline TPH & 1888 & 905 & 2112 & 7820 & 310 & 8130 \\
\hline TPH-GRO & 135 & 74 & 123 & 498 & 34 & 530 \\
\hline TPH-DRO & 1753 & 789 & 2099 & 7694 & 270 & 7970 \\
\hline
\end{tabular}

${ }^{\text {a }}$ Standard Deviation

European Council Decision 2003/33/EC establishes as action value $500 \mathrm{mgKg}^{-1}$ of mineral oils in polluted soils to accept characterization as an inert waste. The value of $500 \mathrm{mgKg}^{-1} \mathrm{TPH}$ in hydrocarbon polluted soils is additionally the notification level for remediation actions in mostly United States (WAC 2001, TACO 2003, TAGM 1994, etc) legislation according to Environmental Protection Agency as displayed by the Association for Environmental Health and Science (AEHS 2003).

The recorded concentrations of TPH at the site signify that the site is polluted by heavy fractions of hydrocarbons. The recorded range of petroleum hydrocarbons values indicates high variability of pollution within the site and demonstrates the heterogeneous nature of the sampled material as a result of several point sources of pollution location and furthermore the geometry of more than one plume.

\subsection{Vertical and horizontal distribution of pollution}

Vertical and horizontal distribution of pollution is displayed in Table 3 using the descriptive statistics of TPH, TPH-GRO and TPH-DRO analyses of the core samples for each horizon.

Table 3 - Summary statistics of hydrocarbons in core samples $(n=8)$ for each horizon

\begin{tabular}{|c|c|c|c|c|c|c|c|}
\hline \multirow{2}{*}{ Parameter } & \multirow{2}{*}{ Horizon } & Mean & Median & $S^{a}$ & Range & Min & Max \\
\hline & & $\mathrm{mgKg}^{-1}$ & $\mathrm{mgKg}^{-1}$ & $\mathrm{mgKg}^{-1}$ & $\mathrm{mgKg}^{-1}$ & $\mathrm{mgKg}^{-1}$ & $\mathrm{mgKg}^{-1}$ \\
\hline \multirow{4}{*}{ TPH } & A & 2061 & 725 & 2653 & 7610 & 420 & 8030 \\
\hline & B & 1658 & 765 & 2627 & 7730 & 400 & 8130 \\
\hline & $\mathrm{C}$ & 1960 & 1315 & 1801 & 4180 & 310 & 4490 \\
\hline & D & 1875 & 1260 & 1570 & 4690 & 770 & 5460 \\
\hline \multirow{4}{*}{ TPH-GRO } & A & 167 & 111 & 144 & 340 & 40 & 340 \\
\hline & $\mathrm{B}$ & 179 & 123 & 161 & 475 & 55 & 530 \\
\hline & $\mathrm{C}$ & 91 & 64 & 84 & 255 & 35 & 290 \\
\hline & D & 103 & 69 & 79 & 215 & 35 & 250 \\
\hline \multirow{4}{*}{ TPH-DRO } & A & 1895 & 609 & 2621 & 7570 & 300 & 7870 \\
\hline & $\mathrm{B}$ & 1478 & 489 & 2633 & 7630 & 340 & 7970 \\
\hline & $\mathrm{C}$ & 1869 & 1245 & 1762 & 4130 & 270 & 4400 \\
\hline & $\mathrm{D}$ & 1772 & 1108 & 1575 & 4780 & 570 & 5350 \\
\hline
\end{tabular}


In order to compare horizontal with vertical variability of petroleum hydrocarbons concentrations at the site, one-way analysis of variance (ANOVA) was applied to the data. The results of this statistical technique showed that horizontal variability is significantly higher than vertical one within each sampled horizon at $95 \%$ confidence level for heavy fractions of hydrocarbons (TPHDRO). In contrast light fractions (TPH-GRO) presented homogenous distribution and equal vertical and horizontal variability within each sampled horizon at $95 \%$ confidence level. The results for TPH, TPH-GRO and TPH-DRO are presented graphically by side by side boxplots for the four sampled horizons (Fig. 2).

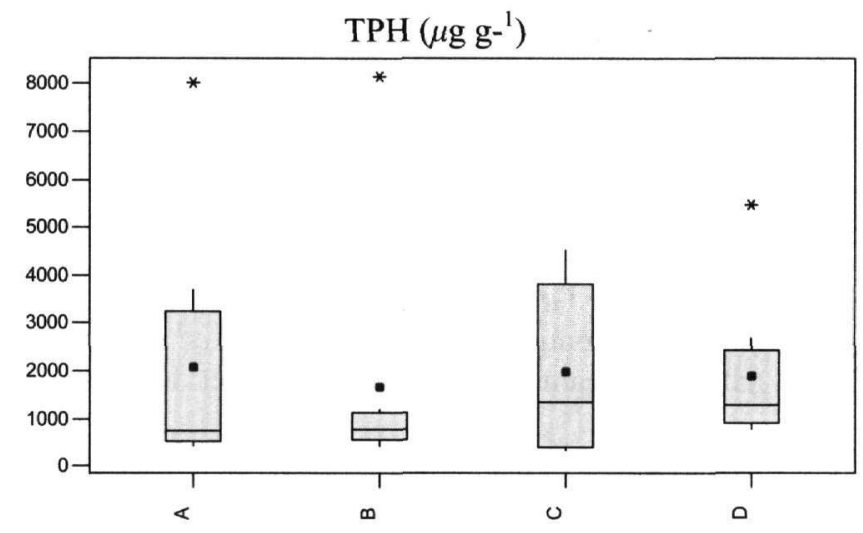

TPH-GRO $\left(\mu \mathrm{g} \mathrm{g}^{-1}\right)$

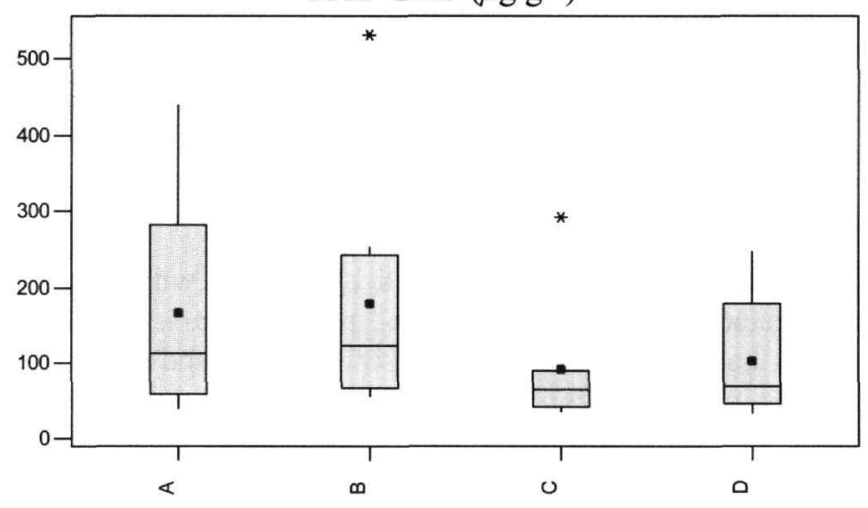

TPH-DRO $\left(\mu \mathrm{g} \mathrm{g}^{-1}\right)$

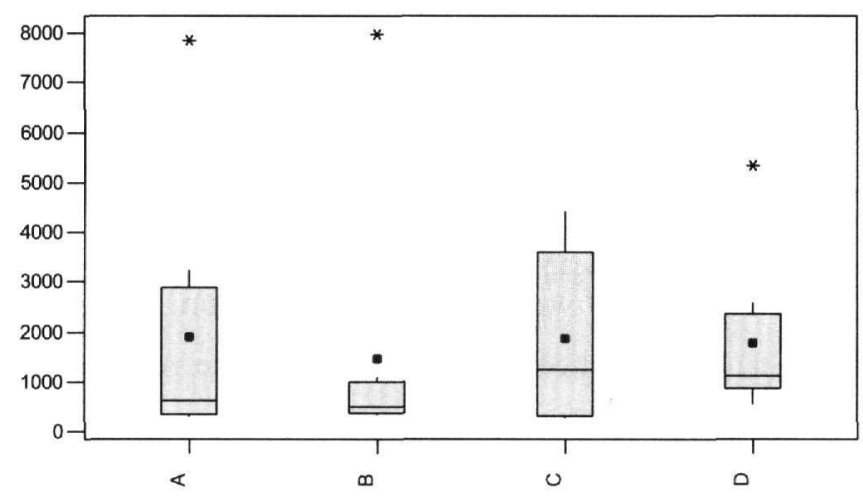

Figure 2 - Boxplots comparing concentrations of TPH, TPH-GRO and TPH-DRO at the four sampled horizons. Solid circles indicate mean values and asterisks indicate outliers 
By looking at the statistics of Table 3 for each sampled horizon it is noticed that TPH fractions presented maximum concentrations in the lower horizons $\mathrm{A}$ and $\mathrm{B}$ as a result of remaining free products in these depths. A peak in median concentrations of heavy hydrocarbons fractions is presented in horizons $\mathrm{C}$ and $\mathrm{D}$. This is attributed to the presence of free products leaks due to erosion of USTs and the migration of hydrocarbons downwards through gravity (TPH Criteria Working Group Series 1997a) and leaching absorbed to soil contaminants by groundwater. Hydrocarbons heavy fractions moved slowly downwards through higher porosity layers such as silty sand and sandy silt formations or following surface deposition and stratum discontinuities. This migration is interrupted at deeper formations because of their lower porosity and higher cohesion such as silt and clay layers where an enrichment of hydrocarbons concentrations occurred.

The significant role of groundwater for hydrocarbon leaching from soil and downwards migration in the saturated zone is further supported by the fact that free products were found in the water column of three monitoring wells close to USTs during sampling and the procedure interrupted. In addition, high hydrocarbon concentrations in water samples were measured from the rest five monitoring wells ranging from 0.6 to $2550 \mathrm{mg} / \mathrm{l}$. The intervention groundwater concentration in petroleum hydrocarbons as issued by Greek state (Government Paper 21/7/79, second issue, No 582) for discharging liquid wastes produced by industrial units of Athens either to EYDAP S.A. sewage system or into naturals streams establishes the target level of $15 \mathrm{mg} / 1$ and $1 \mathrm{mg} / \mathrm{l}$ respectively.

Taking into account the above stated pollution data, the Contractor for the development of the studied property was directed to proceed during construction with an extra financial cost to the appropriate treatment of pumped groundwater prior discharging into the city sewage system and additionally to the management of excavated polluted soil according to the 2003/33/EC European Council Decision. The proposed remediation actions had an important impact on the final investment cost therefore a site assessment study for the recognition of the environmental conditions in brownfield's areas is necessary before any development action takes place.

\section{Conclusions}

An Environmental Site Assessment was performed in parallel with a geotechnical study at a property occupied by a small scale refinery over the past 50 years. Very high concentrations of petroleum hydrocarbons have been measured in soil and groundwater. Heterogeneity of soil pollution has also been estimated horizontally and vertically within the site. It was shown that the horizontal variability of petroleum hydrocarbons is significantly higher than vertical variability as a result of existence of several USTs in the site and more than one detected plumes. Overall the subsoil and groundwater pollution data demonstrate the need for an environmental site assessment in brownfield's areas before any investment and development action takes place.

\section{References}

2003/33/EC: Council Decision of 19 December 2002 establishing criteria and procedures for the acceptance of waste at landfills pursuant to Article 16 of and Annex II to Directive 1999/31/EC.

AEHS, 2003. Survey of States' Cleanup Standards for hydrocarbon-contaminated soils and groundwater. available at http://www.aehs.com/surveys.htm

ASTM E 1527, 2005. Standard Practice for Environmental Site Assessments: Phase I Environmental Site Assessment Process.

ASTM D 4448-85a, 1985. Standard Guide for Sampling Groundwater Monitoring Wells. West Conshohocken, PA. 
EPA/240/R-02/005. Guidance on choosing a Sampling Design for Environmental Data Collection for Use in Developing a Quality Assurance Project Plan, EPA QA/G-5S. Office of Environmental Information, Washington, DC 20460 (December 2002).

IGME, 1986. Geological map, sheet of Athens-Piraeus, scale 1:50000.

Government Paper 21/7/79, second issue, No 582. About discharging liquid wastes from producing operations of industrial areas of Capital to sewage system and natural streams which deflected to the Main Sewage Pipeline that supervised by OLP.

Mackay, D., Shui, W.Y., and Ma, K.C., 1992. Illustrated Handbook of Physical-Chemical Properties and Environmental Fate for Organic Chemicals, vol. I, II, III. Lewis Publishers, Chelsea, MI.

TAGM, 1994. Technical and Administrative Guidance Memorandum \#4046, Determination of soil cleanup objectives and clean up levels, Jan 24 1994. New York Department of Environmental Conservation.

The Dutch List, 4-02-2000. 'Circular on target values and intervention values for soil remediation'. Ministry of Housing, Spatial Planning and Environment, Netherlands.

TACO, 2003. Tiered Approach to Corrective action Objectives, Part 742, Illinois 2003. Title 35: Environmental Protection, Subtitle G: Waste Disposal, Chapter I: Pollution Control Board, Subchapter f: Risk Based Cleanup Objectives.

Total Petroleum Hydrocarbons Criteria Working Group Series, 1997a. Selection of Representative TPH Fractions Based on Fate and Transport Considerations, volume 3, July 1997. TPHCWG Series.Amherst: Amherst Scientific Publishers.

WAC, 2/12/2001. Model Toxics Control Act - Cleanup, Chapter 173-340, Washington Department of Ecology.

USEPA, 1986a. Test Methods for Evaluating Solid Waste, Physical/Chemical Methods, Updates I, II, IIA, IIB, III and IIIA. SW-846. NTIS publication no. PB97-156111 or GPO publication no. 955-001-00000-1. Office of Solid Waste. Washington, DC.

USEPA, 1996b. Environmental Investigations Standard Operating Procedures and Quality Assurance Manual. Region 4, Science and Ecosystem Support Division. Athens, GA. 